\title{
Pengaruh Adaptasi Pembelajaran Secara Online terhadap Hasil Belajar Mahasiswa
}

\author{
Ardiansyah \\ Pendidikan Ekonomi, Universitas Negeri Gorontalo \\ Email: ardiansyah@ung.ac.id
}

\begin{abstract}
Abstrak
Penelitian ini bertujuan untuk menganalisis pengaruh adaptasi pembelajaran yang dilakukan mahasiswa berupa ketersediaan fasilitas belajar secara online dan kesiapan psikis mahasiswa dalam mengikuti pembelajaran secara online terhadap hasil belajar. Pendekatan dan metode yang digunakan dalam penelitian ini berupa pendekatan kuantitatif dengan analsis data menggunakan softwarwe smart PLS 3. Subjek penitian ini adalah mahasiswa prodi pendidikan ekonomi universitas negeri gorontalo. Pengumpulan data dilakukan dengan menggunakan angket dengan media google form. Temuan yang diperoleh antara lain: Pertama, Terdapat hubungan positif dan sigifikan antara fasilitas belajar online dengan hasil belajar Hasil pengujian menunjukan nilai signifikan. Dengan nilai T statistic sebesar 4,904 lebih besar dibandingkan 1.67. Kedua, Terdapat hubungan positif dan sigifikan antara kesiapan psikis belajar online dengan hasil belajar. Hasil pengujian menunjukan nilai signifikan. Dengan nilai T statistic sebesar 3,967 lebih besar dibandingkan 1.67.
\end{abstract}

Kata-kata kunci: Fasilitas belajar, kesiapan psikis, hasil belajar, Covid-19

\section{The Effect Of Online Learning Adaptation On Student Learning Outcomes}

\author{
Ardiansyah \\ Pendidikan Ekonomi, Universitas Negeri Gorontalo \\ Email: ardiansyah@ung.ac.id
}

\begin{abstract}
This study aims at analyzing the effect of student learning adaptation, such as the availability of online learning facilities and students' psychological readiness to participate in online learning, on learning outcomes. This study employs a quantitative approach with the PLS 3 smart software to analyze data. The object is students of the Economic Education Study Program, the State University of Gorontalo. Data was collected using a questionnaire created via Google Form. The findings indicate that there is a positive and significant correlation between online learning facilities and learning outcomes where the $t$ statistic value is 4.904, which is greater than 1.67. Moreover, there is a positive and significant correlation between students' psychological readiness to learn online and learning outcomes where the $t$-statistic value is 3.967, which is greater than 1.67.
\end{abstract}

Keywords: learning facilities, psychological readiness, learning outcomes, Covid-19 


\section{PENDAHULUAN}

Wabah virus corona atau covid -19 mulai mewabah di Wuhan China pada Desember 2019 (Kompas.com, 2020). Pada awal 2020 penyebarannya semakin masif ke beberapa negara termasuk Indonesia dan pada tanggal 2 Maret 2020 di umumkan ada pasien covid-19 pertama di Indonesia (Kompas.com, 2020). Angka kematian akibat Corona terus meningkat setiap harinya dari berbagai negara dan pada tanggal 11 Maret 2020 WHO menetapkan wabah ini sebagai pandemik global (sulsel.idntimes.com, 2020). Hal tersebut mempengaruhi perubahanperubahan dan pembaharuan kebijakan untuk diterapkan.

Untuk mengurangi resiko penyebaran penularan virus corona, maka dilakukan upaya prefentif yang dilakuakan pemerintah dengan menghimbau agar bekerja dari rumah, work from home (WFH), termasuk belajar dan beribadah di rumah bahkan belanja dari rumah. Langkah ini bertujuan untuk mendukung kebijakan social and fisical distancing untuk mencegah penyebaran virus corona.

Anjuran pemerintah untuk work from home (WFH) dan physical and social distancing harus diikuti dengan perubahan modus belajar tatap muka menjadi online. Hal ini didasarkan pada surat edaran Kementerian Pendidikan dan Kebudayaan
Indonesia (Kemendikbud) direktorat pendidikan tinggi no 1 tahun 2020 tentang upaya pencegahan penyebaran covid-19 di lembaga perguruan tinggi.

Melalui isi surat edaran tersebut, pihak kementerian pendidikan dan kebudayaan memberikan instruksi terhadap perguruan tinggi untuk menyelenggarakan pembelajaran work at home atau belajar dari rumah masingmasing.

Semua perguruan tinggi termasuk Universitas Negeri Gorontalo dengan sigap menanggapi instruksi tersebut, salah satunya Universitas Negeri Gorontalo telah siap untuk melakukan upaya antisipasi di lingkungan kampus atas penyebaran virus Covid-19. Di dalam surat tersebut dimuat salah satunya berupa himbauan untuk mengubah pembelajaran tatap muka menjadi pembelajaran jarak jauh.

Sebagai usaha untuk mengurangi penyebaran Covid-19 di lingkungan kampus, Universitas Negeri Gorontalo membuat kebijakan untuk melaksanakan pembelajaran dari rumah. Pembelajaran ini dilakukan menggunakan internet sehingga memungkinkan dosen dan mahasiswa untuk berada di tempat yang berbeda selama proses pembelajaran. dosen dapat membuat materi ajar yang dapat diakses oleh mahasiswa secara online setiap saat. Lokasi mahasiswa dan dosen yang terpisah 
selama pembelajaran meminimalisir terjadinya kontak fisik sehingga pada mampu memunculkan perilaku social distancing.

Penerapan pembelajaran online memungkinkan mahasiswa untuk mengikuti perkuliahan dari rumah masingmasing. Mereka dapat mengakses bahan ajar dan mengirimkan tugas yang diberikan oleh dosen tanpa harus datang ke kampus. Hal ini dapat mengurangi potensi munculnya kerumunan di kampus seperti yang mungkin terjadi jika pembelajaran secara tatap muka di dalam kelas tetap dilaksanakan (Firman \& Rahayu, 2020).

Pembelajaran online merupakan salah satu model pembelejaran yang banyak digunakan di perguruan tinggi pada saat ini dengan memanfaatkan teknologi informasi dalam membantu dosen- mahasiswa dalam kegiatan belajar secara online. Pembelajaran online merupakan kegiatan belajar dengan menerapkan penggunaan teknologi elektronik baik secara konvensional maupun dengan jarak jauh (Rusman, 2013). Pembelajaran online atau e-learning merupakan pembelajaran jarak jauh yang didukung jasa tekonologi seperti telepon, audio, telekonferense, videotape, trasmisi satelit, dan juga web yang semuanya memakai media online (Uno, 2011). Proses Pembelajaran online dapat terlaksana dengan dukungan fasililitas memadai (Bhatia, 2011).

Pembelajaran online memberikan manfaat bagi dosen dan mahasiswa dalam beriterksi jarak jauh dalam proses perkuliahan online kapan dan dimana saja (Pituch \& Lee, 2006).

Kelebihan pada penggunaan media belajar online menurut Bates dan Wulf yaitu (1) mengembangkan interaksi pada pembelajaran), (2) memudahkan interaksi pembelajaran kapan saja dan dimana saja (3) mempunyai jangkauan luas dan (4) memudahkan dalam penyempurnaan serta penyimpanan ateri pembelajaran (Munir, 2009).

Sedangkan menurut setyosari berpendapat bahwa pembelajaran secara online memiliki potensi-potensi, antara lain:, kemudahan mengakses, kebermaknaan belajar dan peningkatan pada hasil belajar (Setyosari, 1996). Pada pembelajaran secara online, mahasiswa dapat berinteraksi secara cepat dan langsung dengan suara, teks, gambar, data, dan video secara timbal balik (Khasanah et al., 2020).

Beberapa penelitian terdahulu menunjukkan bahwa adanya pengaruh positif pembelajaran online terhadap proses pembelajaran. Pembelajaran online dapat meningkatkan semanagat mahasiswa dalam belajar (Rahardja et al., 
2019). Pembelajaran online dapat menumbuhkan partisipasi dan motivasi terhadap kegiatan proses belajar (Gonzalez-Acevedo, 2016; Santoso, 2009; Yilmaz, 2017).

Keadaan psikologi mahasiswa sangat berpengaruh terhadap kulaitas hasil belajar.(Putra, 2017). Dalam pembelajaran online juga perlu diperhatikan kondisi psikis dari mahasiswa selama mengikuti perkuliahan online (Rohman \& Aktif, 2019). Faktor psikis tidak kalah pentingnya dalam proses pembelajaran online sehingga para dosen harus juga memahami kondisi yang dialami mahasiswanya. Para dosen harus memperhatikan beban tugas yang diberiakn kepada mahasiswa dan waktu pelaksanaan proses perkuliahan online. Hal ini perlu dilakukan dosen agar mahasiswa tidak merasa jenuh dan terbebani dengan banyaknya tugas dipikul oleh mahasiswa. selain itu kondisi fasilitas yang kurang memadai seperti jaringan internet lelet membuat komunikasi saat pembelajaran online kurang efektif sehingga menambah kebigungan bagi mahasiswa.

Oleh karena itu, penelitian ini bertujuan untuk meneliti pengaruh ketersedian fasilitas belajar dalam pembelajaran online dan kesepian secara psikis dalam pembelaajran secara online terhadap hasil belajar.
Dalam pelaksanaan pembelajaran online memerlukan media atau alat yang saling terintegrasi sehingga kegiatan perkuliahan bisa terlaksana. Media tersebut berupa laptop atau smart phone dan jaringan internet yang memadai (Mahmoud, 2008). Peralatan berupa laptop dan smart phone memberikan jaminan mobilitas yang memungkinkan mahasiswa dapat mengikuti perkuliahan kapanpun dan dimanapun secara online. Kemampuan laptop dan smartphone memungkinkan mahasiswa untuk bisa mengikuti perkuliahan yang dilaksanaan dalam bentuk virtual dengan menggunakan aplikasi-aplikasi pembelajaran secara online. Salain itu fitur penyimpanan yang ada pada latop atau smartphone memungkinkan materi yang diberikan oleh dosen dapat diakses ulang sewaktu-waktu oleh mahasiswa. Sayangnya beberapa mahasiswa masih terkendala dalam proses pembelajaran online karena tidak memiliki gadget atau laptop.

Berdasarkan pada data penilitan, ada sebanyak 74\% mahasiswa memiliki laptop dan smartphone, sedangkan sisanya $21 \%$ hanya memiki gadget atau smartphone saja dan sisanya sebanyak $5 \%$ tidak memiliki keduanya.

Keterbatasan perangkat seperti gadget aatu laptop menyulitkan bagi mahasiswa dalam proses pembelajaran 
online. Untuk mensiasatinya mahasiswa biasa bisa menggunakan gadget orang terdekat. Selain itu kendala lain yang dihadapi mahasiswa adalah terbatasnya kuota internet yang dimilikinya. Hal ini membuat mahasiswa harus selalu meyediakan kouta internet untuk bisa terhubung pada saat perkuliahan online. Pembelajan online dalam bentuk konferensi video dengan menggunakan apliasi seperti zoom, google meet paling banyak menghabiskan kouta internet. Dikutip dari (Merdeka.com, 2020) untuk pengguna video Zoom dibutuhkan kecepatan internet antara $600 \mathrm{kbps}$ hingga $1,8 \mathrm{Mbps}$. Sementara harga kuota internet dari berbagi provider sangat bervariasi mulai kisaran harga 15 ribu sampai 200 ribu tergantung jumlah kuota dan masa aktif.

Selain itu ketersediaan layanan internet yang stabil adalah hal yang perlu tersedia dalam pelaksanaan pembelajaran online. Kualitas jaringan sangat berpengaruh terhadap kulaitas virtual dan oudio dalam perkulaihan online. Rata-rata kendala yang dihadapi dalam proses pelaksanaan pembelajaran online adalah lemahnya jaringan internet.

Pembelajaran online yang diterpakan pihak kampus membuat pengalaman baru bagi mahasiswa dalam proses belajar mengajar. Pembelajaran online berdampak pada kondisi fisik dan psikis mahasiswa. Faktor tersebut berupa persiapan diri mahasiswa dalam media pembelajaran, koneksi internet di daerah tempat tinggal, bencana banjir, harmonisasi lingkungan sekitar dan keterjaminan pola hidup mahasiswa (Yanti, 2018)

Pembelajaran online dengan menggunakan aplikasi-aplikasi kelas virtual yang dapat diakses melalui layanan internet dengan menggunakan telpon seluler atau laptop. Pembelajaran seperti ini membuat sebagian besar mahasiswa merasa senang dan lebih temotivasi mengikuti pembelajaran online (Rosalina, 2018). Hal ini dikarena pembelajaran online lebih praktis dan lebih memudahkan aktivitas mahasiswa. Melalui pembelajaran online mahasiswa dalam mengikuti pembelajaran online yang diberiakan para dosen kapanpun dan dimanapun. Pembelajaran secara virtual memberikan pengalaman tersendiri bagi mahasiswa dan merasa nyaman dengan pembelajaran online. Pembelajaran online dapat mempengaruhi kepuasan belajar bagi mahasiswa.

Dalam pembelajaran online mahsiswa merasa lebih santai dan nyaman dalm mengikuti pembelajaran. Mahasiswa merasa tidak canggung bertanya dan mengungkaan pendapatnya. ketidakhadiran dosen secara fisik bertatap 
muka merasa mahasiswa tidak tertekan dari teman atau dosen mereka. Pembelajaran secara online juga menumbuhakan kemandirian bagi mahasiswa dalam belajar. Membuat mahasiswa makin mahir penguasaan teknologi dan lebih leluasa mencari mencari referensi atau materi lainnya terkait dalam tugas yang diberiakan oleh dosen. Mahasiswa lebih kreatif dan inovatif dalam menyelesaikan tugas serta dapat mengkondisikan diri mereka senyaman mungkin untuk belajar tanpa aturan normal. Selain itu pembelajaran online membuat mahasiswa lebih dekat dengan keluarga, lebih banyak meluangkan waktu bersama.

Pembelajaran online memilki kendala dalam proses pelaksanaannya. Jarak yang memisahkan antara dosen dan mahasiswa membuat dosen tidak leluasa dalam memantau mahasiswa dalam proses pembelajaran. Terhalangnya jarak membuat pengawasan dosen jadi terbatas sehingga terkadang mahasiswa kurang memperhatikan penjelasan dari dosen.

Permasalahan lain yaitu waktu yang terbatas dalam proses pembelajaran online, membuat tidak semua materi disampaikan secara kompleks sehingga terkadang mahasiswa masih kesulitan untuk memahami pada materi pembelajaran yang diberiakan secara online. Komunikasi dengan dosen melalui aplikasi virtual tidak mampu dalam memberiakan penjelasan menyeluruh mengenai materi yang dibahas. Pada pembelajaran online tugas yang diperoleh mahasiswa dari dosen terkadang banyak sehingga mahasiswa merasa kewalahan dalam mengerjakan tugas, hal ini membuat sebagian mahasiswa merasakan terbebani untuk mengerjakan tugas kuliah.

\section{METODE}

Jenis penelitian mengunakan metode kuantitatid dengan analisis data menggunakan Smart PLS 3. Subjek penelitian adalah mahasiswa semester I pada Prodi Pendidikan Ekonomi Fakultas Ekonomi Universitas Negeri Gorontalo yang aktif mengikuti pembelajaran online. Terdapat 85 mahasiswa yang mengisi angket atau memberikan tanggapan dalam angket tersebut.

Pengumpulan data dilakukan melalui via angket online dengan google form yang diberiakan kepada mahasiswa. Variabel pada penelitian ini dikolompokkan menjadi dua yaitu variabel independen dan variabel dependen. Variabel independen dalam penelitian ini adalah ketersedian vasilitas belajar dalam pembelaajaran secara online dan kesiapan psikis mahasiswa dalam mengikuti pembelajaran secara online. 
Sedangkan variabel dependennya yaitu hasil belajar mahasiswa.

Ketersediaan fasilitas belajar adalah segala sesuatu yang dibutuhan mahasiswa dalam mengikuti pembelajaran yang dilakukan secara online sedangkan keadaan psikis adalah keadaan mental mahasiswa dalam mengikuti pembelajaran secara online.

Hasil belajar adalah pencapian mahasiswa dalam memahami materi pembelajaran yang dapat diukur dengan tes tertentu dan diwujudkan dalam bentuk nilai atau skor setelah menempuh proses pembelajaran.

\section{HASIL DAN PEMBAHASAN}

\section{Model Pengukuran (Outer Model)}

Pada model pengukuran outer model digunakan beberapa teknik dalam menganalisa data dengan smart PLS yaitu convergent validity, discriminant validity dan composite reliability.

\section{Convergent validity}

Convergent validity dengan melihat tabel outer loadings. Batas loading factor sebesar 0,5. Apabila nilai pada loading faktor > 0,5 maka convergent validity dinyatakan terpenuhi dan apabila nilai loading faktor < 0, 5 maka konstruk harus di drop dari analisis. Berikut ini adalah hasil uji convergent validity dalam penelitian in:
Tabel 1. Uji Convergent Validity

\begin{tabular}{ccc}
\hline Variabel & Indikator & $\begin{array}{c}\text { Outer } \\
\text { Loeding }\end{array}$ \\
\hline $\begin{array}{c}\text { Fasilitas } \\
\text { belajar }\end{array}$ & $\mathrm{X} 1.1$ & 0.782 \\
online & $\mathrm{X} 1.2$ & 0.733 \\
(X1) & $\mathrm{X} 1.3$ & 0.774 \\
Kesiapan & $\mathrm{X} 1.4$ & 0.859 \\
psikis & $\mathrm{X} 2.1$ & 0.742 \\
Belajar online & $\mathrm{X} 2.2$ & \\
(X2) & $\mathrm{X} 2.3$ & 0.863 \\
Hasil Belajar & $\mathrm{X} 2.4$ & 0.919 \\
(Y) & $\mathrm{Y} .1$ & 0.778 \\
& & \\
& $\mathrm{Y} .2$ & 0.865 \\
& $\mathrm{Y} .3$ & 0.731 \\
\hline
\end{tabular}

Sumber data yang diolah 2020

Data pada tabel 1 menunjukkan bahwa setiap indikator dari variabel penelitian memiliki nilai outer loading $\geq 0,5$ sehingga memenuhi syarat convergent validity.

\section{Discriminant Validity}

Pengujian discriminant validity dapat dilihat dari nilai cross loading masingmasing indikator variabel laten berbeda dengan variabel lainnya. Berikut tabel Prestasi uji Discriminant Validity.

Tabel 2. Discriminant Validity

\begin{tabular}{cccc}
\hline Indikator & $\begin{array}{c}\text { Fasilitas } \\
\text { belajar }\end{array}$ & $\begin{array}{c}\text { Kesiapan } \\
\text { Psikis }\end{array}$ & $\begin{array}{c}\text { Hasil } \\
\text { Belajar }\end{array}$ \\
\hline X1.1 & $\mathbf{0 . 7 8 2}$ & 0.507 & 0.534 \\
X1.2 & $\mathbf{0 . 7 3 3}$ & 0.413 & 0.483 \\
X1.3 & $\mathbf{0 . 7 7 4}$ & 0.655 & 0.644 \\
X1.4 & $\mathbf{0 . 8 5 9}$ & 0.666 & 0.829 \\
X2.1 & 0.567 & $\mathbf{0 . 7 4 2}$ & 0.596 \\
X2.2 & 0.717 & $\mathbf{0 . 8 6 3}$ & 0.717 \\
X2.3 & 0.644 & $\mathbf{0 . 9 1 9}$ & 0.701 \\
X2.4 & 0.549 & $\mathbf{0 . 8 7 8}$ & 0.665 \\
Y1 & 0.506 & 0.471 & $\mathbf{0 . 7 0 9}$ \\
Y2 & 0.776 & 0.767 & $\mathbf{0 . 8 6 5}$ \\
Y3 & 0.626 & 0.607 & $\mathbf{0 . 7 3 1}$ \\
Y4 & 0.684 & 0.644 & $\mathbf{0 . 9 0 0}$ \\
\hline
\end{tabular}

Sumber data yang diolah 2020 
Pada tabel 2 menunjukkan bahwa setiap indikator memiliki nilai cross loading paling besar pada variabel pembentuknya apabila dibandingkan dengan nilai cross loading variabel lain. Hal tersebut menunjukkan bahwa indikator dalam penelitian memenuhi syarat validitas diskriminan.

\section{Uji Reliabilitas}

Pengujian reliabilits dengan melihat pada nilai Cronbach's alpha. Suatu variabel laten bisa dikatakan mempunyai realibilitas yang baik apabila nilai composite reliability lebih besar dari 0,7. Hasil uji realibilitas dapat dilihat pada tabel 3.
Tabel 3. Hasil Uji Reliabilitas

\begin{tabular}{lcc}
\hline Variabel & $\begin{array}{c}\text { Cronbach } \\
\text { Alpha }\end{array}$ & $\begin{array}{c}\text { Composite } \\
\text { Reliability }\end{array}$ \\
\hline $\begin{array}{c}\text { Fasilitas Belajar } \\
\text { online }\end{array}$ & 0.800 & 0.867 \\
$\begin{array}{c}\text { Kesiapan psikis } \\
\text { belajar online } \\
\text { Hasil Belajar }\end{array}$ & 0.873 & 0.914 \\
\hline $\begin{array}{l}\text { Sumber data yang diolah 2020 } \\
\text { Pada tabel } 3 \text { menunjukkan bahwa nilai }\end{array}$ \\
Cronbach Alpha untuk setiap variabel $\geq 0,7$ \\
sehingga dapat \\
dikatakan \\
kriteria reliabel.
\end{tabular}

\section{Pengujian Model Struktural (Inner Model)}

Pengujian pada Inner Model dilakukan untuk mengetahui hubungan antar variabel berdasarkan nilai yang diperoleh dari path coefficient pada gambar 1 berikut.

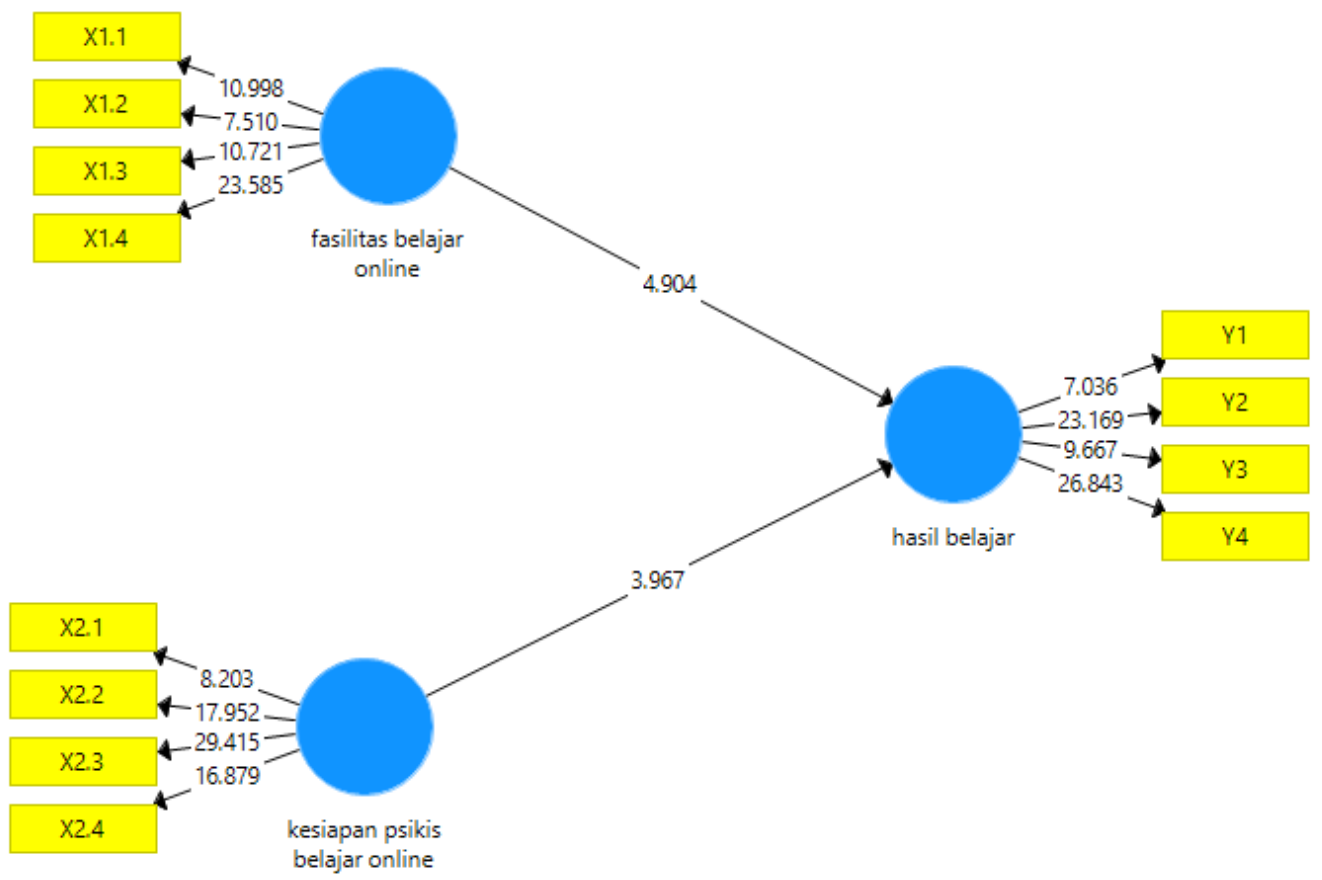

Gambar 1. Inner Model (Model Struktural) 
Pada gambar 1 menunjukkan Inner model (model struktural) yang digunakan untuk melihat hubungan antar, nilai signifikansi, konstruk dan R-square pada model penelitian. Dalam menilai model dapat dilihat dari nilai R-square untuk tiap variabel laten dependen. Tabel berikut menunjukkan nilai R-squere pada variabel laten dependen yaitu

Tabel 4 Nilai R-Square

\begin{tabular}{cc}
\hline Variabel & R-Square \\
\hline Hasil Belajar & 0.747
\end{tabular}

Sumber daya yang diolah 2020

Tabel 4 menunjukkan nilai R-square untuk variabel hasil belajar diperoleh sebesar 0,747. Hasil ini menunjukkan bahwa $74,7 \%$ variabel hasil belajar dapat dipengaruhi oleh variabel fasilitas belajar online dan variable kesiapan psikis belajar online. Sedangkan 25,3 \% dipengaruhi variabel lain yang tidak disertakan dalam penelitian ini.

\section{Pengujian hipotesis}

Keputusan pengujian hipotesis penelitian diterima atau ditolak dilakukan dengan melihat output nilai statistik path coefficient baik secara Direct Effect (Pengaruh Langsung) dan Indirect Effect (Pengaruh tidak Langsung). Signifikan hipotesis dilihat dari tabel Path Coefficients besarnya nilai $\mathrm{t}$ hitung $<\mathrm{t}$ tabel. Berikut Prestasi Pengujian Hipotesis dari Path Coefficient secara Direct Effect (Pengaruh Langsung).

Tabel 5. Output Prestasi Estimasi Direct Effect (Pengaruh Langsung)

\begin{tabular}{lccccc}
\hline \multicolumn{1}{c}{ Hubungan } & $\begin{array}{c}\text { Original } \\
\text { Sample } \\
(\mathbf{O})\end{array}$ & $\begin{array}{c}\text { Sample } \\
\text { Mean (M) }\end{array}$ & $\begin{array}{c}\text { Standard } \\
\text { Deviation } \\
\text { (STDEV) }\end{array}$ & $\begin{array}{c}\mathbf{T} \\
\text { Statistic } \\
\text { (O/STDEV) }\end{array}$ & $\begin{array}{c}\text { P } \\
\text { VALUES }\end{array}$ \\
\hline $\begin{array}{l}\text { Fasilitas belajar online } \rightarrow \\
\text { Hasil Belajar }\end{array}$ & 0.520 & 0.511 & 0.106 & 4.904 & 0.000 \\
$\begin{array}{l}\text { Kesiapan psikis belajar } \\
\text { online } \rightarrow \text { hasil Belajar }\end{array}$ & 0.409 & 0.421 & 0.103 & 3.967 & 0.000 \\
\hline
\end{tabular}

Sumber daya yang diolah 2020

Berdasarkan tabel di atas dapat disimpulkan bahwa;

1) X1 (fasilitas belajar online) berpengaruh signifikan dan positif terhadap $Y$ (hasil belajar,

2) X2 (kesiapan psikis belajar online) berpengaruh signifikan dan negatif terhadap Y (hasil belajar).

\begin{abstract}
Hubungan fasilitas belajar online (X1) terhadap hasil belajar $(Y)$

Hasil pengujian menunjukan bahwa hubungan fasilitas belajar online (X1) dengan hasil belajar (Y) menunujukan nilai signifikan. Dengan nilai T statistic sebesar 4,904 lebih besar dibandingkan 1.67. Nilai original sample adalah positif yaitu sebesar
\end{abstract}


0,520 hasil ini menunjukan bahwa fasilitas belajar online (X1) berpengaruh signifikan dan positif terhadap hasil belajar (Y).

Dengan demikian Hipotesis 1 pada penelitian ini diterima. Artinya, dalam penelitian ini variabel fasilitas belajar online (X1) berpengaruh terhadap variabel hasil belajar (Y) secara positif dan signifikan.

\section{Hubungan kesiapan psikis belajar online}

\section{(X2) terhadap hasil belajar (Y)}

Hasil pengujian menunjukan bahwa hubungan kesiapan psikis belajar online (X1) dengan hasil belajar (Y) menunujukan nilai signifikan. Dengan nilai $T$ statistic sebesar 3,967 lebih besar dibandingkan 1.67. Nilai original sample adalah positif yaitu sebesar 0,409 hasil ini menunjukan bahwa kesiapan psikis belajar online (X2) berpengaruh signifikan dan positif terhadap hasil belajar $(\mathrm{Y})$.

Dengan demikian Hipotesis 2 pada penelitian ini diterima. Artinya, dalam penelitian ini variabel kesiapan psikis belajar online (X1) berpengaruh terhadap variabel hasil belajar $(\mathrm{Y})$ secara positif dan signifikan.

\section{SIMPULAN}

Terdapat hubungan positif dan sigifikan antara fasilitas belajar online (X1) dengan hasil belajar (Y). Hasil pengujian menunjukan nilai signifikan. Dengan nilai $T$ statistic sebesar 4,904 lebih besar dibandingkan 1.67. Secara umum mahasiswa dapat beradaptasi dalam proses pelaksanaan pembelajaran online dengan fasilitas yang mereka miliki.Fasilitas seperti gadget dan laptop, kuota internet serta jaringan internet. Meskipun tidak semua daerah memilki jaringan internet yang stabil tetapi mereka bisa mengikuti perkuliahan online.

Terdapat hubungan positif dan sigifikan antara kesiapan psikis belajar online (X2) dengan hasil belajar (Y). Hasil pengujian menunjukan nilai signifikan. Dengan nilai T statistic sebesar 3,967 lebih besar dibandingkan 1.67. Pembelajaran online juga memberikan pengaruh terhadap keadaan psikis mahasiswa. Secara umum mahasiswa merasa senang dengan pelaksanaan pembelajaran online meskipun ada beberapa hal yang membut suasana hati mahasiswa merasa kurang senang seperti jaringan yang lelet seta tugas yang diperoleh dari dosen lebih banyak

\section{DAFTAR REFERENSI}

Bhatia, R. P. (2011). Features and Effectiveness of E-learning Tools. Global Journal of Business Management and Information Technology, 1(1), 1-7. http://www.ripublication.com

Firman, F., \& Rahayu, S. (2020). Pembelajaran Online di Tengah Pandemi Covid-19. Indonesian Journal of Educational Science (IJES), 2(2), 81-89. https://doi.org/10.31605/ijes.v2i2.659 
Gonzalez-Acevedo, N. (2016). Technologyenhanced-gadgets in the Teaching of English as a Foreign Language to Very Young Learners. Ideas on Implementation. Procedia - Social and Behavioral Sciences, 232, 507-513. https://doi.org/10.1016/j.sbspro.2016.10 .070

Khasanah, D. R. A. U., Pramudibyanto, H., \& Widuroyekti, B. (2020). Pendidikan Dalam Masa Pandemi Covid-19. Jurnal Sinestesia, 10(1), 41-48.

Kompas.com. (2020a). Diumumkan Awal Maret, Ahli: Virus Corona Masuk Indonesia dari Januari. Kompas.Com. https://www.kompas.com/sains/read/20 20/05/11/130600623/diumumkan-awalmaret-ahli--virus-corona-masukindonesia-dari-januari

Kompas.com. (2020b). Timeline Wabah Virus Corona, Terdeteksi pada Desember 2019 hingga Jadi Pandemi Global. Kompas.Com.

https://www.kompas.com/tren/read/202 0/03/12/113008565/timeline-wabahvirus-corona-terdeteksi-pada-desember2019-hingga-jadi

Mahmoud, S. S. (2008). A Proposed Model for Distributing e-Courses Content through Mobile Technology Architectures. 2(1), 39-54.

Merdeka.com.

https://www.merdeka.com/teknologi/inikuota-data-yang-terpakai-untuk-groupcall-zoom-dan-hangout-meet-sudahtahu.html. Merdeka.Com.

Munir, M. I. (2009). Pembelajaran Jarak Jauh Berbasis Teknologi Informasi dan Komunikasi. Alfabeta.

Pituch, K. A., \& Lee, Y. kuei. (2006). The influence of system characteristics on elearning use. Computers and Education, 47(2), 222-244. https://doi.org/10.1016/j.compedu.2004. 10.007

Putra, M. F. P. (2017). Pengaruh aspek psikologis terhadap hasil belajar mahasiswa olahraga Kurdi. Jurnal SEGAR (Sehat Dan Bugar).

Rahardja, U., Lutfiani, N., Handayani, I., \& Suryaman, F. M. (2019). Motivasi Belajar Mahasiswa Terhadap Metode Pembelajaran Online iLearning + Pada Perguruan Tinggi Student Learning Motivation Against iLearning + Online
Learning Method in Higher Education. Jurnal Sisfotenika, 9(2), 192-202.

Rohman, A., \& Aktif, P. (2019). Dampak Psikologi Belajar Dalam Pembelajaran Aktif Bagi Peserta Didik Madrasah Ibtidaiyah. 10, 51-70.

Rosalina, M. (2018). Analysis The Use of Schoology E-Learning Towards Students' Learning Motivation Enhancement in STKIP Surya. Indonesian Journal of Science and Education, 2(1), 89. https://doi.org/10.31002/ijose.v2i1.614

Rusman. (2013). Model-model Pembelajaran. Rajagrafindo Persada.

Santoso, E. (2009). Pengaruh Pembelajaran Online terhadap Prestasi Belajar Kimia Ditinjau dari Kemampuan Awal Siswa. 1117.

Setyosari, P. (1996). Pembelajaran Sistem Online: Tantangan dan Rangsangan. https://media.neliti.com/media/publicati ons/220215-pembelajaran-sistem-onlinetantangan-dan.pdf

sulsel.idntimes.com. (2020). [BREAKING] WHO Umumkan Penetapan Virus Corona Sebagai Pandemi. Sulsel.Idntimes.Com. https://sulsel.idntimes.com/news/indone sia/rosa-folia/breaking-who-tetapkancovid-19-sebagai-pandemik-regionalsulsel

Uno, H. B. \& N. L. (2011). Teknologi Komunikasi \& Informasi Pembelajaran. Bumi Akasara.

Yanti, P. (2018). Pengaruh Persiapan Dan Kondisi Lingkungan Terhadap Fisik Dan Psikis Mahasiswa Dalam Pembelajaran Online Di Rumah Aja. 1(1), 1-8. http://dx.doi.org/10.1016/j.cirp.2016.06. 001\%0Ahttp://dx.doi.org/10.1016/j.powt ec.2016.12.055\%0Ahttps://doi.org/10.10 16/j.ijfatigue.2019.02.006\%0Ahttps://doi. org/10.1016/j.matlet.2019.04.024\%0Ahtt ps://doi.org/10.1016/j.matlet.2019.1272 52\%0Ahttp://dx.doi.org/10.1016

Yilmaz, R. (2017). Exploring the role of elearning readiness on student satisfaction and motivation in flipped classroom. Computers in Human Behavior, 70, 251260. https://doi.org/10.1016/j.chb.2016.12.08 5 